\title{
The theological significance of the Isaiah citation in Mark 4:12
}

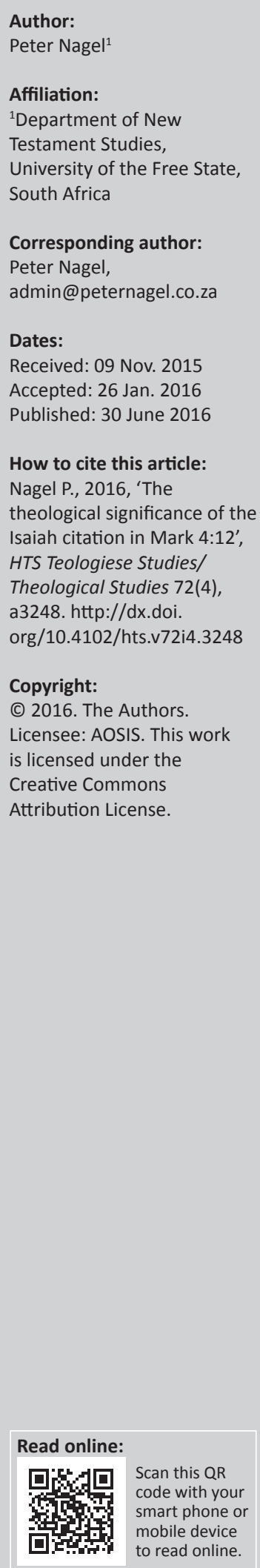

The well-known passage Mark 4:1-34 is no stranger to New Testament scientific scrutiny, not to even mention the hotly debated phrases in Mark 4:10-12. To avoid repetition, the aim with this article is to determine the extent of the impact the Isaiah 6:9-10 citation in Mark 4:12 might have had on the interpretation and understanding of Mark 4:1-34 and the Gospel as a whole. The theory is that the citation in Mark 4:12, especially within Mark 4:1-34, is foundational for understanding the Markan gospel as a 'parable'. Moreover, the redactional inclusion of the concept of 'the Twelve' will prove to be a vital contribution in understanding the Markan gospel as a 'parable'. Arguing this theory will include evaluating the parable theory in Mark 4:10-12, followed by determining the interpretative effect the explicit citation in Mark 4:12 had on Mark 4:10-12 and its larger literary context (Mk. 4:1-34). This will be followed by concluding remarks and suggestions.

\section{Introduction}

Much has been written about the parables, especially those attested in Mark 4:1-34. ${ }^{1}$ These include investigations into the so-called 'parable theory' (cf. Mk. 4:10-12 and Mk. 4:33-34). The theory to be argued in this article is that Mark 4:12 in the context of Mark 4:10-12 relating to the redactional concept of 'the Twelve' is fundamental for understanding the Markan gospel as parable. ${ }^{2}$ To argue this theory, it would be necessary to show the conceptual impact the Isaiah 6:9, 10 in Mark 4:12 had on Mark 4:10-12 and subsequently, Mark 4:1-34. It will also be required to determine the significance of Mark 4:10-12 within the larger literary structure of Mark 4:1-34. Finally, one would have to show the importance of Mark 4:1-34 in terms of the Markan gospel. It will be argued in the first section that the citation in Mark 4:12 informs the theological significant concepts in Mark 4:10-12. In the second section I will show that Mark 4:10-12 as parable theory defines Mark 4:1-34 as a parable pericope. In conclusion I will give reasons and make suggestions why and to what extent Mark 4:12 informs and defines the theological character and nature of Mark's gospel. Declaring a few presuppositions should be in order:

1. Parables constitute the proclamation of God's kingdom as its primary concern.

2. The tension between the 'revealed' and 'concealed' mystery of God's kingdom is a central concept in the Markan gospel.

3. Mark 4:1-34 as parable context is a flagship among Markan parables. ${ }^{3}$

4. Mark 4:10, Mk 4:11 and Mk 4:12 respectively offer fundamental insight ${ }^{4}$ into the understanding of Mark 4:1-34 as parable.

5. The Isaiah 6:9, 10 citation in Mark 4:12 informs the theological significant concepts in Mark $4: 10-11 .^{5}$

6. The thematic and conceptual relationship between 'the Twelve' (Mk. 3:13, 14:4:10; 5:25; 6:7) and Mark 4:10-12 is key in understanding the Markan gospel as a parable. ${ }^{6}$

Crossan (1992:146) defines parables as 'an extended metaphor or simile frequently becoming a brief narrative, generally used in biblical times for dialectic purposes'. According to Snodgrass (1992), parables are best defined as

1.Jones (1978:519-538); Franco (1981:240-244); Sellin (1983:508-530); Tuckett (1988:1-26); Dautzenberg (1990:38-62); Sellew (1990:234-267); Heil (1992:271-286); also see the history of work done on Mark 4:1-34, at least up until the 1986 in Marcus (1986:1-6); Kirkland (1977:1-21); Marcus (1984:557-574); Vincent (1986:179-182) and that of the most recent study by MacComiskey (2008:59-85).

2.A parable defined as being ambiguous in nature; a method of communication that requires a certain amount of confusion is adopted as a workable definition.

3.Scott (1990:22) argues that Mark concentrates his parables in Chapter 4.

4.These insights are brought to literature in virtually every phrase of Mark 4:10-12.

5.The redactional concept of 'the Twelve' (Mk. 3:13, 14; 4:10; 5:25; 6:7) is considered important in arguing the theory that Mark 4:12, in relation to Mark 4:10-12 defines the Markan gospel as parable (see Mark 6:7, 43; 8:19; 9:35; 10:32; 11:11; 14:10 in relation to 'the Twelve').

6.See also Mark 6:7, 43; 8:19; 9:35; 10:32; 11:11; 14:10. 
stories with two levels of meaning; the story level provides a mirror by which reality is perceived and understood. In effect, parables are imaginary gardens with real toads in them. (p. 591)

Newman (2000:909) adds that the this 'short fictitious stories that illustrate a moral attitude or religious principle' function on two levels: 'earthly story' and 'heavenly meaning'. If it is reasonable to define parables as short stories about something that is recognisable and identifiable, with the aim to communicate a 'divine' principle of sorts that is in turn not as obvious. And if it is sensible to understand the Markan gospel as a story about the teachings of Jesus about things that are at first glance familiar, but as soon as the subject familiarise itself, the realisation that things are not as it appears to be, but that there is more to it. Then it is plausible to consider and classify the Markan gospel as a parable. The latter notion is further supported by the following realistic observations:

1. The opening emphasis on the 'desert' ministry of John the Baptist as opposed to Jerusalem as the religious centre.

2. The 'others' recognising and understanding the divine identity of Jesus (e.g. Mk. 1:23-25).

3. The fact that Isaiah $6: 9,10$ was used with the parable content of Mark 4:1-34, especially together with Mark 4:10-11.

4. The followers of Jesus not grasping the full extent of who Jesus really is.

5. The nature of how the gospel ends in Mark 16:8.

The first pertinent question is how significant is the Isaiah 6:9, 10 citation in Mark 4:12. In an attempt to answer this question, Mark 4:12, within the conceptual context of Mark 4:10-12, will be investigated in depth.

\section{Mark 4:12 and its significance for Mark 4:10-12 as Parable Theory ${ }^{7}$ Mark 4:10}

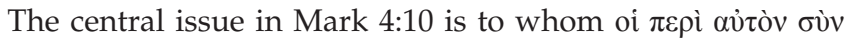

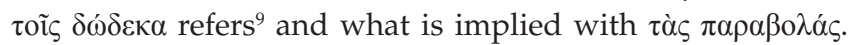
Noteworthy is the fact that the events that follow occurred

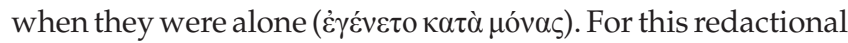
composition to be effective, it was deemed necessary to change from a public to a more private setting. The question is, who precisely is this exclusive group of people? The redactor clearly regarded 'the Twelve' as forming part of this exclusive group, but are they the ones posing the question? Did 'those around him' that accompanied 'the Twelve' pose the question? Or did 'those around him' including 'the Twelve' raise the question? France (2002:186) argues that

7.Cf. (Haufe 1972:413-421) and (Räisänen 1973). For Scott (1990:22) Mark 4:11-12 introduces the so-called 'hardening theory.

8.A few text critical alternatives are suggested pertaining to Mk 4:10. First, $\mu \alpha \theta \eta \tau \alpha$

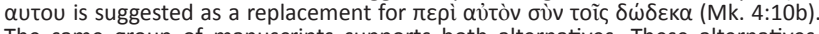
The same group of manuscripts supports both alternatives. These alternatives, however, do not pose any threat to the integrity of the verse, nor does it alter the meaning or theological significance in any way.

9.(Turner 1993:3-146) comments that we have in Mark four elements, the 'Lord', the Twelve, the disciples outside the Twelve, and lastly the multitude. The intermediate Twelve, the disciples outside the Twelve, and lastly the multitude. The intermediate
elements distinguished by Mark are that the Twelve are now a group by themselves 'among' the disciples, 45 .
Mark used the term ö $\chi \lambda$ o $\varsigma$ as denoting the larger group that followed Jesus, and that ox $\chi \lambda$ o s should be identified with oi $\pi \varepsilon \rho i ̀$ av̉ $\tau$ óv. Pesch (1976:237) views 'the Twelve' as indicating the Hauptvermittler in the Jesus tradition and that oi $\pi \varepsilon p i$ av̉ $\tau$ óv are not to be identified with 'the Twelve' in Mark 4:10.10 The shift from a public (Mk. 4:3-8) to a private (Mk. 4:10) audience probably set the stage in the pre-Markan tradition for the interpretation in Mark 4:14-20. ${ }^{11}$ The phrase 'those around Him with the Twelve' most likely began simply as 'those

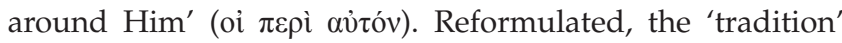
began with those in close proximity to Jesus asking about the parable were given the interpretation (Mk. 4:14-20). ${ }^{12}$ Gnilka (1978:162) argues that Mark inserted $\delta \omega \delta \delta \varepsilon \kappa \alpha^{13}$ into the text, while Marcus (2000:302) and Hultgren (2000:454) identify 'those around him' with the community of believers. Hultgren (2000:454), in addition, notes that the community of believers should be divided into two groups, those that followed Jesus in his earthly ministry, and those that followed him in the time of Mark.

France (2002:194-195) offers a 'simple' solution, and rightfully

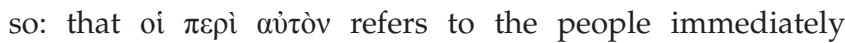
surrounding Jesus (cf. Acts 13:13). They are the ones who are 'doing the will of God', and who enquire about the parables. From a semantic point of view, it is indeed possible to assume that any follower of Jesus at any given point could have been

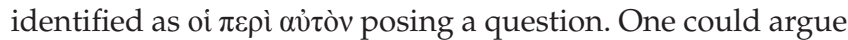
that the redactor intended to transform the question into a more theological loaded inquiry with the insertion of бòv $\tau$ oĩ $\delta \omega \delta \varepsilon \varepsilon \alpha \alpha$. The argument is that the redactor composed $\mathrm{Mk}$ 4:10-12, while drawing from pre-Markan material for the most part, especially Isaiah 6:9-10. The aim with the insertion was to place emphasis on 'the Twelve' not just as the 'official' disciples, but as representative of the 'chosen' people. If the gospel of Mark projects a negative stance towards the disciples of Jesus and a positive attitude towards 'the Twelve',

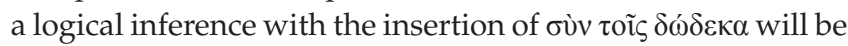
that the redactor regarded 'the Twelve' as opposing the 'disciples'. This notion appeals positively towards a possible parable theory in Mark 4:10-12. It seems as if the disciples are the ones who do not understand the mission and teachings of Jesus, but 'the Twelve' are the chosen ones that would complete the mission (cf. Mk 3:13-14; 6:7). What follows is a short excursion into the concept of 'the Twelve'.

\section{'[T]the Twelve'}

The interpolation of Mark 3:13-16 not only establishes the backdrop against which 'the Twelve' in Mark 4:10 is to be

10.Pesch (1976:237) further comments that katò $\mu$ ovas is a Hapax Legomenon and should be understood as a pre-Markan tradition.

11.Guelich 1989:203. Scott (1990:234) notes that it has become customary, at that time, in gospel scholarship to speak in general terms of a pre-Markan source for much of Mark 4:1-34.

12.Guelich 1989:204.

13. It could be that the function of the term $\delta \dot{\omega} \delta \varepsilon \kappa \alpha$ extends far beyond a group appointed by Jesus. For example, Mark 5:25 (a woman that suffered from haemorrhages) and Mark 5:42, the 12 -year-old girl, the daughter of Jairus that was raised from the dead; Mark $5: 42$, the 12 -year-old girl, the daughter of Jairus that was raised from the dead,
the twelve baskets filled with the loaves of bread in Mark 6:43 (cf. Mk. 8:19). Mark 3:13-19 and Mark 6:7-12 present a positive view of the twelve, but a more negative 3:13-19 and Mark 6:7-12 present a positive view of the twelve, but a more negative
view is presented in Mark 9:33-37; Mark 10:32-34 is positive (cf. Mk. 11:11); negative is of course Mark 14:10-11 (Judas Iscariot) cf. Mark 14:17-21cf. Mark 14:43. 
understood, but it also gives one insight into the intent of the redactor. Again, the public space (Mark 3:7-11) will soon be replaced by a more private and exclusive space (Mk. 3:13-16). A need for a more private space is required to avoid being trampled upon by the crowd of people (Mk. 3:9). The names of 'the Twelve' are not considered important, but rather the concept of 'the Twelve.' Koch (2008:130-132) argues that the only conclusion to be drawn from the concept of 'the Twelve' is that the list itself is the only pre-Markan tradition in Mark 3:13-16. This did not stop the redactor from using the concept of 'the Twelve' for his own benefit, even though the writer might not have been familiar with the 'original' meaning of 'the Twelve.' It is fair to infer that the concept of 'the Twelve' signals theological significance, being exclusive and inclusive simultaneously, while opposing the followers of Jesus. In Koch's own words: 'That Jesus was abandoned by his disciples is part of the pre-Markan narration of the Passion, but the emphasis on 'the Twelve' is part of the comprehensive literary activity of Mark.' The function of 'the Twelve' is not only to be with Jesus and to cast out demons (cf. Mk. 3:14-15), but they are responsible to reaffirm Jesus' spiritual identity, not as someone that is possessed by Beelzebul (cf. Mk. 3-22), but the one with the authority to send out 'the Twelve' as people with authority over unclean spirits (Mk. 6:7). 'The Twelve' not only grasped Jesus' mission, but had insight into his identity. They shared in his private space (cf. Mk. 9:35); they were the ones with the responsibility to make known the mystery of God's kingdom, illustrated so well in Mark 10:32ff:

\begin{abstract}
... He took 'the twelve' aside again and began to tell them what was to happen to him, saying, 33 See, we are going up to Jerusalem, and the Son of Man will be handed over to the chief priests and the scribes, and they will condemn him to death; then they will hand him over to the Gentiles; 34 they will mock him, and spit upon him, and flog him, and kill him; and after 3 days he will rise again. ${ }^{14}$ (Mk. 10:32ff)
\end{abstract}

One could argue that having Judas Iscariot in your midst does not paint a positive picture of the significant 'Twelve.' A counter-argument is that if it was not for Judas Iscariot, the death, hence the resurrection, would not have taken place (cf. Mk, 11:11; 14:10). A leading figure during the Passover meal (Mk 14:17, 20); the one responsible for the capturing of Jesus (Mk, 14:47), Judas is the significant other reflecting the essential identity and function of 'the Twelve' as the bringers of 'good' news with 'bad' consequences. The message enlightens and confuses simultaneously; that makes sense and is in itself senseless. Having the concept of the 'Twelve' (Mk, 4:10) and the citation taken from Isiah 6:9-10 (Mk. 4:12) as part of a theological significant composition, within the context of the parables Mk 4:1-34 does call for extraordinary literary effects. 'The Twelve' were re-convened by Peter, were re-installed by the appearance of the risen Lord and so their function was to form the nucleus of the new people of God;15 they represented the new eschatological people of God. ${ }^{16}$ Not

14.See also the entering into the Temple in Jerusalem - Mark 11:11.

15.Koch 2008:137.

16.Koch 2008:140. only did they set the benchmark for the new eschatological people of God and with that defined the character of such people, but the message they proclaimed became the benchmark; in fact for the redactor, the Markan gospel was the benchmark. They received the mystery of God (Mk 4:11) in the form of a parable and because their function was to proclaim, the message about Jesus (the Markan gospel) became the mystery of God's kingdom, a parable.

The most likely candidates posing the question to Jesus

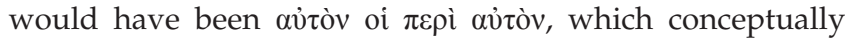
refers to the followers or disciples of Jesus. They are also the ones who received the mystery of God's kingdom (Mk. 4:11). If that is indeed the case, it would imply that the third person

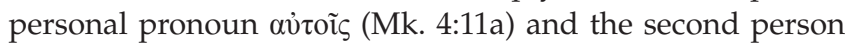
personal pronoun $v_{\mu i \tau}(\mathrm{Mk} .4: 11 \mathrm{~b})$ originally refer back to the

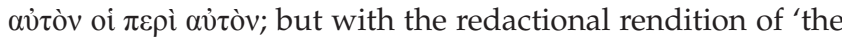
Twelve', they are also included.

\section{Mark 4:11 ${ }^{17}$}

Mark 4:11 is significant in that the mystery of God's kingdom is shared with viñv, which probably refers back to aviòv oi $\pi \varepsilon \rho \grave{\alpha} \alpha$ vò̀ and 'the Twelve.' The structure of the verse unfolds as follows:

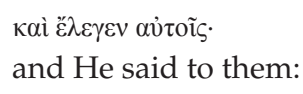

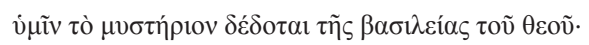

you have been given the mystery of God's kingdom;

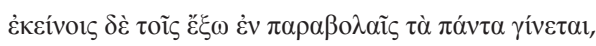

but for those outside, everything remains in parables,

The theological significant concepts introduced in this verse

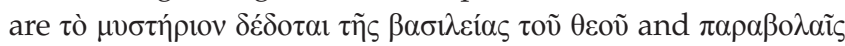

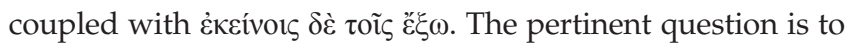

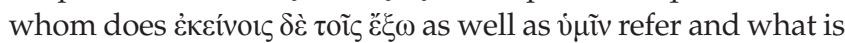
the conceptual relationship between the 'mystery of God's kingdom' and 'parables'. Finally, one should also determine as to what $\tau \grave{\alpha} \pi \alpha ́ v \tau \alpha$ entails. Baird (1957:202) suggests that $\tau \grave{\alpha}$

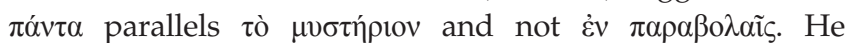
introduces a parallelism between Mark 4:11a and Mark 4:11b by means of a scheme, from where he develops the assumption that the use of $\pi \alpha$ óv $\alpha$ in Mark 4:34 refers to those things expounded to the disciples. ${ }^{18}$ Some scholars suggest 'all things' include the proclamation of Jesus up until that time and further. ${ }^{19}$ Pesch (1976:239) is of the opinion that the ivo

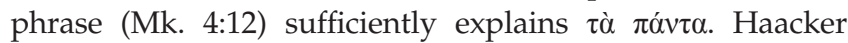
(1971:221), while referring to Bornkamm, writes that Mark 4:11a could refer back to Mark 4:3-8, from where he poses the

17.Text-critically speaking, Mark 4:11 appears intact for the most part; an alternative reading for $\tilde{\varepsilon} \xi \omega$ and vivetat is suggested, while a significant amount of manuscript witnesses 'omit' tà rávta. None of these proposed alternatives, if accepted, pose any threat to the current interpretation of Mark 4:11 in relation to Mark 4:10 and Mark 4:12

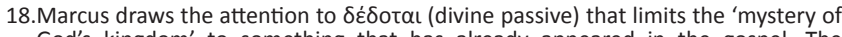
God's kingdom' to something that has already appeared in the gospel. The 'mystery of God's kingdom' is given in parables and through the parable of the sower, in this particular context, 66. He further points out the limitations of Baird's sower, in this particular context, 66 . He further points out the limitations of Baird's
schematization, and adds that the dative introduces both Mk 4:11a [ن́niv] and Mk

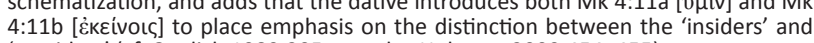
'outsiders' (cf. Guelich 1989:205; see also Hultgren 2000:454-455).

19.Guelich (1989:208); cf. France (2002:198); Haufe (1972:417). 
possibility that Mark 4:11 could have been a Vorform des Wortes interpreting parables, and because of this Mark 4:11 should not be viewed as an answer to the question raised in Mk 4:10. Pesch (1976:238) confirms Haacker's assumption and adds '... eine urkirchliche Entstehung des Logions an. ${ }^{20}$ Gnilka (1978:163) builds on this line of thought by arguing that if $\tau$ ò $\mu v \sigma \tau$ prov and $\dot{\varepsilon} v \pi \alpha \rho \beta \beta \Delta \lambda \alpha i \bar{s}$ are indeed regarded as being parallel then $\dot{\varepsilon} v \pi \alpha \rho \alpha \beta \mathrm{o} \lambda \alpha \overline{\mathrm{i}} \varsigma$ is to be understood as 'riddle' ${ }^{21}$ In the words of Haufe (1972:414-415): ,das Logion Mk4,11fist eine vormarkinische, aber nachösterliche Gemeindebildung ... das Logion hat ursprünglich mit den Gleichnisreden Jesu weder im vorösterlichen noch im nachösterliche Sinne irgendetwas zu tun.'

Focant (1997:150-151) addresses the issues by drawing a parallel between Mark 4:10-12 and Mark 3:20-35, not only to place emphasis on the two groups present in Mk 4:11, but also to illuminate Mark's understanding of the two groups. Ambrozic (1967:220) concludes that Mark offers two opposing views regarding parables. On the one hand, they are riddles which keep the 'outsiders' in darkness. On the other hand, the outsiders do not understand the parables. Maier (1995:160-162) does not agree with Ambrozic's view (1967:220), upheld by a number of scholars, ${ }^{22}$ that 'in parables' should be interpreted as 'riddles'. He suggests that '̇ं $\pi \alpha \rho \alpha \beta$ o $\alpha$ iic should rather be viewed as a 'pädagogisches Mittel, das Nachdenken nötigt. ${ }^{23}$ France (2002:198), in agreement with Maier, argues that $\dot{\varepsilon} v \pi \alpha \rho \alpha \beta$ o $\lambda \alpha i \varsigma_{\zeta}$ should be interpreted in the context of Jesus' parabolic teaching (particularly Mk 4:1-34), and within the Synoptic gospels in general. ${ }^{24}$

The author's intention was not to introduce multiple secrets concerning God and his kingdom with the notion of $\tau$ ò $\mu v \sigma \tau$ íprov. Neither was his aim to suggest 'exclusive' knowledge concerning God's kingdom. ${ }^{25}$ He wanted to emphasise the position of judgement in correlation with the immediate experience. ${ }^{26}$ For Gottschalk (1971:122) the concept $\tau$ ò $\mu v \sigma \tau$ ๆ́prov is thus apocalyptic in nature, which has not been used by Jesus himself, but the early Church has applied it in that manner. The 'mystery of God's kingdom' is 20.Suhl (1965:146) states that Mark 4:11 is a typical Palestinian anaesthetic parallelism.

21.Cf. Guelich (1989:205).

22.Cf. Suhl (1965:147); Pesch (1976:239); Gnilka (1978:163) among others. Brown (1973:62) is of the opinion that the 'mystery of God's kingdom' (Mark 4:11) is not the same as Jesus' identity. For Brown, if one is to deny a connection between
Mark 4:11a and the allegorical interpretation of the parable of the sower (Mk $4: 14-20)$, then it is possible to deny his conclusion that the 'mystery of God's kingdom' is indicated by the parables, 63 .

\section{Cf. France (2002:198)}

24.Räisänen (1973:63) formulates his understanding as follows: 'Auch die auffällige Singularform tò $\mu$ uбńpıov lässt sich gut aus dieser rückblickenden Perspektive verstehen ... fast die Gemeinde hier das Ganze der besonderen Lehre, die sie von de

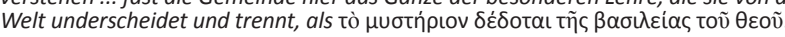

25.Brown (1973:62) argues that the 'mystery of God's kingdom' (Mk 4:11) is not the same as Jesus' identity. For Brown, if one is to deny a connection between Mark 4:11a and the allegorical interpretation of the parable of the sower (Mk. 4:14-20), then it is possible to deny his conclusion that the 'mystery of God's kingdom' is indicated by the parables, 63. Bolkenstein (1973:102) suggests that the declared indicated by the parables, 63. Bolkenstein (1973:102) suggests that the declared mystery is that Jesus is the Messiah, the parables are thus concerned with the the relationship between parables and mystery, Novum Testamentum, 19:3.

26.In the words of Bolkenstein (1973:102) 'Bij hen geloof en zonder geloof moet het word van het Rijk duister blijven. In het geloof alleen worden gelijkenissen verstaan, verstaan namelijk in hun relatie met Jezus en het gebeuren, dat in Hem, in verborgenheid, plaatsvindt. revealed by the proclamation of Jesus. Such a revelation, so to speak, reveals God's reign as an eschatological mystery. Pesch (1976:239) formulates it as follows: Wahrscheinlich

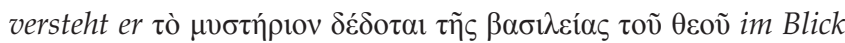
auf vv. 26-29.30-32 als die verborgene Gottesherrschaft.

Marcus (2000:68) pleas for a reasonable inference that the 'mystery of God's kingdom' for the author of the Markan gospel would be 'equal' to the parable of the sower. If one would further consider the Semitic backdrop (cf. Dn. 2) of this concept, then it is clear that the mystery is indeed revealed (cf. Mk. 4:3-8), but it is not yet understood. Marcus (2000:70) argues that the allegorical interpretation (Mk. 4:1420 ) is a further revelation of the 'mystery of God's kingdom'. Due to the redaction process the parable of the sower implies that the 'mystery of God's kingdom' should be viewed in terms of the eschatology. The glory of the 'mystery of God's kingdom' is already visible to those who have faith in Jesus Christ, which will be revealed in its entire splendour with the parousia. ${ }^{27}$ The great wonders and signs, with the many healings, are shown to the world as the 'mystery of God's kingdom'. ${ }^{28}$ All things in riddles stand antithetically to the 'mystery of God's kingdom'. ${ }^{29}$ It is a specific understanding, disclosed to certain people (the disciples) through the words and deeds of Jesus. ${ }^{30}$ Those who know Jesus only as a worker of wonders does not understand Him at all, for the secret of the kingdom of God is that Jesus must die as the crucified Messiah. ${ }^{31}$ France (2002:198) understands the 'mystery of God's kingdom' as that which is revealed through the

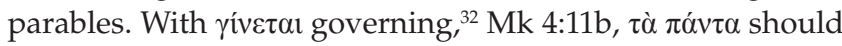
be interpreted as referring to that which is currently happening (the teaching, the parable, the question, and that which is given (Mk 4:11a), on the one hand. And on the other hand, $\tau \grave{\alpha} \pi \alpha \dot{v} \tau \tau \alpha$ should also be viewed as referring to Jesus' proclamation in general. In summary, ${ }^{33}$ the mystery of God's kingdom refers to the parables in particular; it includes the words and deeds of Jesus as well as the identity of Jesus and

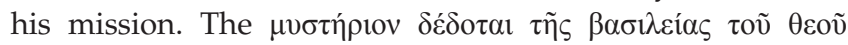
suggests the following:

1. The specific parable context of Mark 4:1-34.

2. It includes parables as literary communicative tool in general - ensured by the redactor's inclusion of $\dot{\varepsilon} v$ $\pi \alpha \rho \alpha \beta$ oגaĩ (Mk 4:10).

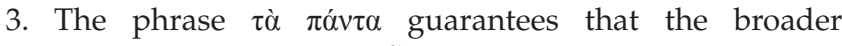
proclamation of Jesus, $\tilde{\eta} \lambda \theta \varepsilon v$ ó 'I

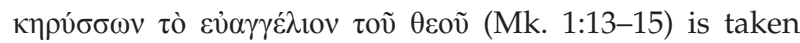
into account.

4. Fourthly, this 'revealed' mystery is concealed in the

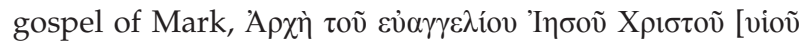
$\theta \varepsilon \circ \tilde{u}]$ (Mk. 1:1).

27.Marcus (2000:79); cf. Maier (1995:161).

28.Van Bruggen (1988:107)

29.Guelich (1989:208).

30. Hultgren (2000:458).

31.Hays (1996:76).

32.Cf. Van Bruggen (1988:107).

33.Cf. Van Bruggen (1988:106). 


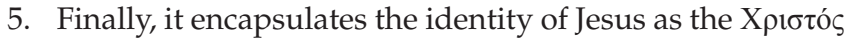
and кúpios.

Given the evidence and their underlying arguments, it is

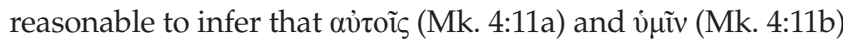

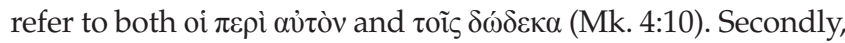
the mystery of God's kingdom is revealed and concealed through parables. The mystery of God's kingdom is at best a parable, but a parable which holds at its core the intent to reveal what it in fact conceals. If the mystery of God's kingdom remains a parable, it means that the revelation method has not been penetrated as to get to what it aims to communicate. The ability to do this is to qualitatively and quantitatively form part of God's new people through the message of Jesus as the risen 'Lord.' It has been suggested, and logically so, that

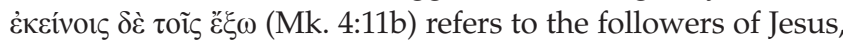
his so-called disciples, who do not fully grasp the mission of Jesus and therefore almost everything thought by Him would

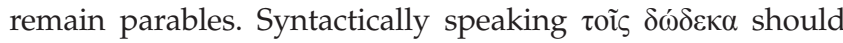
also be included, but theologically speaking they are excluded based on the redactional reworking of the material. Secondly, it refers to those that did not accompany Jesus in the boat, or rather, those not considered to be part of the inner circle. With the addition of 'the Twelve' in Mark 4:10 a third possibility becomes available. Everyone that does not form part of the new eschatological people of God represented by 'the Twelve', does not have the capacity to go beyond the parable as a method to unravel the parable, whilst the mystery of God's kingdom is revealed. Just as much as the parables would want to reveal the mystery of God's kingdom, so too does the Markan gospel want to declare who Jesus is and what He has done and by doing so, the mystery of God's kingdom becomes a parable. ${ }^{34}$ The 'revelation' of God's kingdom does not necessarily imply understanding so as to label anyone at any given time as 'outsider' or 'insider'. In fact, just as the mystery of God's kingdom reveals while concealing, so too does

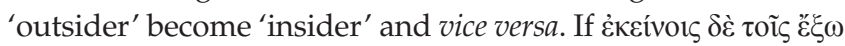

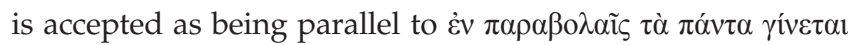
(Mk $4: 11 b)$, then $\tau \grave{\alpha} \pi \alpha ́ v \tau \alpha$ refers to 'the mystery of God's kingdom' and 'everything' it encapsulates. Everything that symbolises or refers to the kingdom of God remains \&ेv $\pi \alpha \rho \alpha \beta o \lambda \alpha \tilde{c}{ }^{35}$ The phrase $\dot{\varepsilon} v \pi \alpha \rho \alpha \beta$ o $\lambda \alpha i \bar{\varsigma}$ is also a technical term inserted and rendered by the redactor to introduce the parables (cf. Mk. 4:3-8, 26-29, 30-32) in particular, but to also call the essence of the content matter mentioned above into mind. The conclusion is that those people who are not (1) participating in the 'hearing and questioning of the parables' and (2) listening to the teachings and forming part of the eschatological people of God; will also not recognise the identity of Jesus, which will result in rejecting the message of the Markan gospel. At first glance, and the most obvious

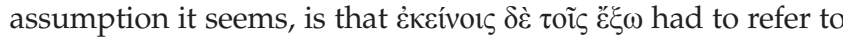
the remaining crowd left behind on the shores of the sea of Galilee. It could not have been referring to those surrounding Jesus, not to even mention 'the Twelve'. A closer reading of the

34.Kirkland (1977:19) concurs that the earliest traditions support the view that Jesus used the parables to hide and to reveal simultaneously.

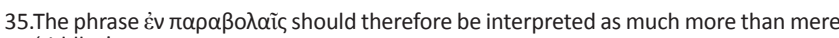
'riddles'.

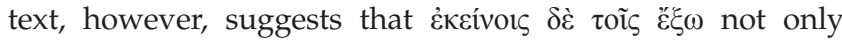
includes those who accompanied Jesus on the boat, but they seem to be made out to be the guilty ones. The allusion to Isaiah 6:9-10 in Mark 4:12 sheds some light and gives some

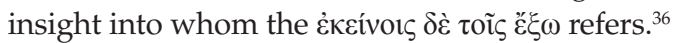

\section{Mark 4:12}

The aim here will not be to determine the 'original' meaning behind Isaiah 6:9-10, neither is the intent to understand the literary backdrop of this citation. The focus, rather, will fall on the concepts introduced in Mark 4:12 in the light of Mark 4:10 and Mark 4:11. The structure of the verse presents itself as follows:

iv $\alpha$

so that

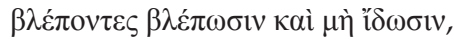

those who are looking see, but perceive not,

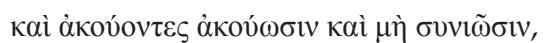

and those who are listening hear, but understand not,

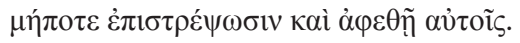

lest they turn around not to be healed.

Past and very recent discussions dealing with Isaiah 6:9-10 in Mark 4:12 have been dominated by the search for the meaning and function of the two conjunctions i $i v \alpha$ and $\mu \eta \tilde{\sigma} \tau \tau \varepsilon$. These discussions produced three possible outcomes:

1. Final clause (evident of Targumim dependence)

2. Purpose clause (evident of LXX dependence)

3. Result clause (if Mark 4:12 is interpreted as a later interpolation, somewhat distinct from Mark 4:11).

These two conjunctions are indeed crucial elements to be considered when interpreting Mark 4:12, ${ }^{37}$ but the discussion should be extended to other facets of this verse as well. With the redactional 'insertion' and allusion to Isaiah 6:9, 10, the redactor achieved its theological aim. That is to connect the parables of Jesus with the concept of 'the Twelve', the mystery of God's kingdom and the 'stubbornness' concept communicated in Isaiah 6:9-10. The opinion here is that, with

36.Also see the study of Goulder (1991:289-304).

37.The iv $\alpha$ introduces the fulfilment of the Scripture, and therefore iv $\alpha$ could also have a consecutive meaning, Suhl (1965:149), contra Hanson (1983:67-69), who proposes a consecutive meaning if iv $\alpha$ is interpreted against the backdrop of

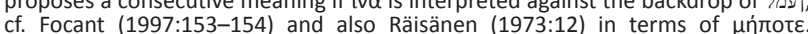
cf. Focant (1997:153-154) and also Räisänen (1973:12) in terms of $\mu \eta n \pi 0 \tau \varepsilon$. According to Räisänen, the use of $\mu$ n $\pi$ rot $\varepsilon$ introducing a final clause confirms the final use of 'iva. The latter use establishes, by means of Jesus' proclamation, a separation between 'believers' and 'unbelievers'. It also refers to the temporary (1970) (1978:170-172) argues that Mark has both the unbelievers' and Israel in mind. He sees it as a reference-fulfilment scheme, introduced by iv $\alpha$ connected to $\check{\varepsilon} \xi \omega$ (Mk. 4:11b). According to Gottschalk (1971:123) the final and causal use of iv $\alpha$ roots the fulfilment of Isaiah's prophecy and clarifies the goal of Jesus' parables. The reality that there are some people not believing in Jesus, are theologically interpreted by Isaiah 6:9-10, and it is introduced by ïva, which also connects to tà róvta (Mk. 4:11b; Pesch 1976:239). Whoever composed this periphrastic translation has given it a telic or final meaning, and has applied it to the purpose of Jesus' parables (Evans 1982:132). According to Guelich (1989:211), iva would express the purpose

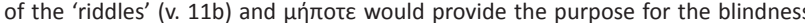
and deafness (v. 12a). Guelich interprets iv $\alpha$ as functioning epexegetically with and deafness (v. 12a). Guelich interprets iv $\alpha$ as functioning epexegetically with reference to the scriptures (Guelich 1989). Suhl (1965:151) has championed the targumic influence of $\mu$ n $\pi 0 \tau \varepsilon$, whilst referring to Marxen, who suggests that Mark reveals a typical Jewish time fever and therefore Mark could have taken the Targum paraphrase as reference to the believers. Marcus (2000:307), Hultgren (2000:458) and France (2002:199) argue that iv $\alpha$ could not introduce anything other than purpose clause. Marcus is of the view that with the purpose clause taken up in Mark 4:21-22, it becomes evident that the truth should be concealed and in turn be revealed. 
establishing this connection, the redactor opened up the possibility to interpret Mark 4:10-12 as fundamental for Mark 4:1-34 and the Gospel as a whole. ${ }^{38}$ According to Guelich (1989:213-214), Isaiah 6:9-10 indicates an epexegetic, and not the purpose for the enigmatic character of Jesus' teachings and that the text underscores that the 'outsiders' fail to perceive the real moment in Jesus' ministry, and therefore Mark understands his whole gospel as a parable. Those following Jesus understand God's salvation plan and Kingdom, but for the 'outsiders' Jesus is using the pedagogical method of the parables. ${ }^{39}$ The allusion to Isaiah 6:9-10 could well be viewed as irony, ${ }^{40}$ and therefore God's message will be met with differences or hostility. It does not necessarily refer to divine intention, thus the first mentioned would fit well into Mark 4:10-11. ${ }^{41}$ The mystery theory is not just a literary phenomenon, but it is the very origin of Jesus' words and deeds. Jesus is among the Christian community and through faith and within the religious cult, $\mathrm{He}$ is viewed as the Messiah and Lord.42

Another aspect of Mark 4:12 deserves attention, that is the meaning and underlying concept of the Greek verbs for 'seeing', 'hearing', 'perceiving' and 'understanding'. The predominant meaning of $\beta \lambda \varepsilon \dot{\psi} \omega$ is see, look at; as of sense perception; in contrast to being blind be able to see; figuratively, of spiritual perception see, understand, be aware of. ${ }^{43}$

Marcus (1986:157) suggests that $\beta \lambda \varepsilon \dot{\pi \varepsilon v v}$ would, semantically speaking, feel at home when designated as an empirical phenomenon as distinct from religious certainty. In Mark

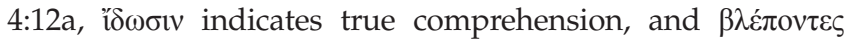
$\beta \lambda \varepsilon ́ \pi \omega \sigma \mathrm{v}$ are perceptions that fall short of that. ${ }^{44}$ The same

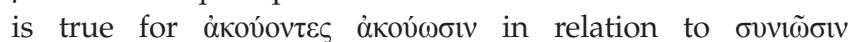
(Mk. 4:12b). The meanings proposed for the root verb $\sigma v v i ́ \eta \mu$ is 'set together 'to understand' ${ }^{45}$ or to be intelligent. ${ }^{46}$ Marcus

38. Evans (1981:235) argues that if Mark viewed the allusion to Isaiah 6:9-10 as an analogy to the rejected ministry of Jesus, then it is indeed comprehendible that
Mark would have related the words of the prophetic judgement to the experience Mark would have related the words of the prophetic judgement to the experience
of his Lord. He also suggests that the Isaiah text provides theological basis for the of his Lord. He also suggests that the Isaiah text provides theological basis for the
purpose of Jesus' parables and possibly for his ministry as a whole (Evans purpose of Jesus' parables and possibly for his ministry as a whole (Evans
1982:126-127). He further argues that Isaiah 6:9-10 and Isaiah 55:10-11 linked by 1982:126-127). He further argues that Isaiah 6:9-10 and Isaiah 55:10-11 linked by the catchword 'seed' provide the basis for a skillfully developed Midrash in Mar 4:1-20 (Evans 1985:466). Guelich (1989:213) concedes that it can well be that Isaiah 6:9-10 could explain why 'all things' are in 'riddles' in terms of divine judgement, because the allusion to Isaiah 6:9-10 is closer to the Targum, and Mark 4:11b and Mark 4:12 describes those who had not responded positively to Jesus' ministry about the kingdom; they found all things in 'riddles'.

39.Maier (1995:162-163).

40.Marcus (1986:169-172) calls this apocalyptic irony.

41.France (2002:201). According to Räisänen (1973:121), the logion has a didactical goal, with the parables as communication method, while Gottschalk (1971:125) suggests that the so-called parable theory presents Jesus' logion and parables as eschatological, and the parable logion reveals Jesus as the Son of Man; according to him Jesus' identity and life is parabolic in nature, concealing and revealing. For Pesch (1976:240) the parables would have stayed hidden if one does not think about it, and asking questions to enable one to understand. The parables will stay about it, and asking questions to enable one to understand. The parables will stay
hidden to the 'outsiders', and it will also be difficult to grasp for Mark and his hidden to the 'outsiders', and it will also be difficult to grasp for Mark and his
community. The reason for the latter is due to the Hellenistic-Jewish influence community. The reason for the latter is due to the Hellenistic-Jewish influence.
Gnilka (1978:170-172), in turn, argues that for Mark the parables are 'riddles' logions, representative of the negative aspect of the 'mystery of God's kingdom' and even more related to the negative aspect surrounding Israel.

42.Gnilka 1978:168-169.

43.Friberg, Friberg \& Miller 2000:92; cf. Louw \& Nida 1996:277. The sense of becoming aware of or taking notice of something.

44.Arndt et al. 1979:220.

45.Liddell 1996:777.

46.Louw \& Nida 1996:237
(1986:159) argues that 'hearing' in Mark 4:12a and 12b speaks of both the 'outsiders' comprehension of the parables on a superficial level and of their failure to penetrate beyond the realm of appearance to that true insight. The term $\beta \lambda \dot{\varepsilon} \pi$ ov $\tau \varepsilon \varsigma$ (Mk. 4:12b) should also be viewed in relation to $\beta \lambda \dot{\varepsilon} \pi \omega \sigma \mathrm{v} v$ in Mk 4:3, which refers to the crowd to which Jesus started teaching (Mk. 4:1-2); the same would apply for ákov́ovtes

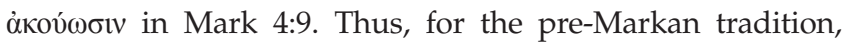
regarding the parable of the seeds or soil (Mk 4:3-8), everyone located at the sea of Galilee is called to listen (listening in terms of $\sigma u v i \tilde{\omega} \sigma v$, not just 'hearing'). The latter is further strengthened

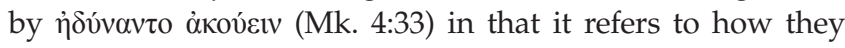
responded to the call made in Mark 4:3 and Mark 4:9. The reference to 'hearing' in Mark 4:33 will also imply a larger group or crowd. Finally, one cannot begin to interpret these verbs in Mark 4:12 without consulting Mark 4:21-25. The

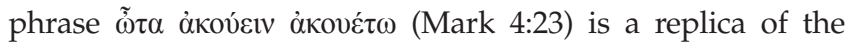

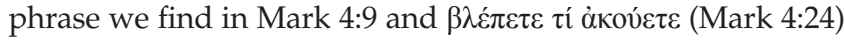
also recalls the notions offered by the allusion to Isa 6:9-10 in Mk 4:12, to mind. To conclude: what the words in Mark 4:12 (Is. 6:9, 10) want to convey is the 'normal' act of seeing and hearing as opposed to a deeper level of grasping, understanding and perceiving. This of course fits in perfectly with parables, mystery of the Kingdom and the followers or disciples.

But what has the redactor achieved with the allusion to Isaiah 6:9-10 in Mark 4:12? For one, the acts of seeing, hearing, perceiving and understanding, in the negative, would encompass parables, the mystery of God's kingdom, the words and deeds of Jesus, including the Markan gospel. Secondly, the verbal third person plurals do not merely refer to the crowds left behind on the shores, it includes 'those around Jesus' as well as 'the Twelve', whilst addressing the receptors of the gospel message. Thirdly, the iv $\alpha$ clause does not necessarily suggest a grammatical connection with Mark

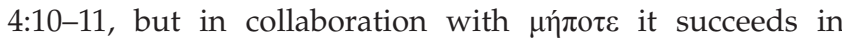
extending the impact of Verstockung beyond the parameters of Mark 4:10-12 and Mark 4:1-34 to the gospel as a whole.

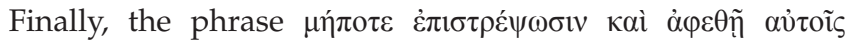
strengthens the plausibility to consider the 'gospel' message of Mark as parabolic-dualistic and apocalyptic-eschatological in nature. It is as if Isaiah 6:9, 10 was written for Mark 4:1-34, not that it was, but just to emphasise how flawless it suits the literary context of Mark 4:10-12 in particular and Mark 4:134 in general. In fact, the Verstockung idea as presented in Isaiah 6:9, 10 reveals something of the nature of the Markan gospel.

\section{Conclusion}

Mark 4:10-12 as redactional composition encompasses everything 'gospel' and 'parable'. It includes outsiders and insiders that translocate from one group to another, depending on the understanding of the mystery of God's kingdom. The insider grasps the mystery of God's kingdom and with that the parables become gospel, but as soon as this stage has been reached, the insider becomes confused and divorces his understanding of these matters by which he becomes an outsider. The inclusion of 'the Twelve' (Mk. 4:10) 
and the allusion to Isaiah 6:9-10 (Mk. 4:12) reinforces the assumption that this composition extends far beyond the parable context in Mark 4:1-34. In fact, Mark 4:10-12 is the key to unlock the Markan gospel and at the same time, locking it allowing studies such as these to continue. The inclusion of 'the Twelve' as concept and the allusion to Isaiah 6:9-10 as part of the parable theory composition not only governs Mark 4:1-34 as parable context, but it transforms Mark 4:1-34 as pivotal for understanding the mission of Jesus through parables, of which the Markan gospel is the parable par excellence.

\section{Acknowledgements Competing interests}

The author declares that he has no financial or personal relationships which may have inappropriately influenced him in writing this article.

\section{References}

Ambrozic, A.M., 1967, 'Mark's concept of the parable', Catholic Biblical Quarterly 29, 220-227.

Arndt, W., Gingrich, F.W., Danker, F.W. \& Bauer, W., 1979, A Greek-English lexicon of the New Testament and Other Early Christian Literature : A translation and adaption of the Fourth Revised and Augmented Edition of Walter Bauer's GriechischDeutsches Worterbuch zu den Schrift des Neuen Testaments und der ubrigen urchristlichen Literatur, University of Chicago Press, Chicago, IL.

Baird, J.A., 1957, 'A pragmatic approach to parable exegesis: Some new evidence on Mark 4 11, 33-34', Journal of Biblical Literature 76(3), 202. http://dx.doi. org $/ 10.2307 / 3261569$

Bolkenstein, M.H., 1973, Het Evangelie naar Marcus, 3rd edn., Uitgeverij G.F. Callenbach, Nijkerk. (De Prediking van het Nieuwe Testament).

Brown, S., 1973, 'The secret of the Kingdom of God (Mark 4:11)', Journal of Biblical Literature 92, 60-74. http://dx.doi.org/10.2307/3262755

Crossan, J.D., 1992, “Parable', in D.N. Freedman (ed.), The Anchor Yale Bible Dictionary, pp. 146-152, Doubleday, New York.

Dautzenberg, G., 1990, 'Mk 4:1-34 als Belehrung über das Reich Gottes Beobachtungen zum Gleichniskapitel', Biblische Zeitschrift 32(1), 38-62.

Evans, C.A., 1981, 'A note on the function of Isaiah, VI, 9-10 in Mark IV', Revue Biblique $88,235$.

Evans, C.A., 1982, 'The Function of Isaiah 6:9-10 in Mark and John', Novum Testamentum 24, 124-138. http://dx.doi.org/10.1163/156853682X00024

Evans, C.A., 1985, 'On the Isaianic background of the sower parable', Catholic Biblical Quarterly 47, 464-468.

Focant, C., 1997, 'La recontextualisation d'Is 6:9, 10 en Mc 4,10-12, ou un example de non-citation', in C.M. Tuckett (ed.), The Scriptures in the Gospels, pp. 143-175, Leuven University Press, Leuven.

France, R.T., 2002, The Gospel of Mark, Wm. B. Eerdmans, Grand Rapids, MI. (New International Greek Testament Commentary).

Franco, E., 1981, 'Parola e regno (Mc 4,1-34)', Rassegna di teologia 22, 240-244.

Friberg, T., Friberg, B. \& Miller, N.F., 2000, Analytical lexicon of the Greek New Testament, Baker Books, Grand Rapids, MI. (Baker's Greek New Testament Library).

Gnilka, J., 1978, Das Evangelium nach Markus 1. Teilband Mk 1-8:26, Evangelisch Katolisch Kommentar II/1, Benziger Verlag, Zürich.

Gottschalk, I., 1971, 'Die Evangelische Parabeltheorie Markus 4,10-12', in C. Bourbeck (ed.), Gleichnisse aus Altem und Neuem Testament, Gleichnisse aus den Evangelien, pp. 120-125, Ehrenfried Klotz Verlag, Stuttgart.
Goulder, M.D., 1991,' Those outside (Mk 4:10-12)', Novum Testamentum 33(4), 289304. http://dx.doi.org/10.1163/156853691X00097

Guelich, R.A., 1989, Mark 1-8:28, Word Biblical Commentary 34A, Word Books Publisher, Dallas, TX.

Haacker, K., 1971, 'Erwägungen zu Mc IV 11', Novum Testamentum 13, 221.

Hanson, A.T., 1983, The living utterances of God. The New Testament exegesis of the Old, Darton, Longman and Todd Ltd, London.

Haufe, G., 1972, 'Erwägungen zum Ursprung der sogenannten Parabeltheorie Markus 4:11-12', Evangelische Theologie 32, 413-421. http://dx.doi.org/10.14315/evth$4: 11-12$, E
1972 -jg30

Hays, R.B., 1996, The moral vision of the New Testament. A contemporary introduction to New Testament ethics, T\&T Clark, Edinburgh.

Heil, J.P., 1992, 'Reader-response and the narrative context of the parables about growing seed in Mark 4:1-34', Catholic Biblical Quarterly 54(2), 271-286.

Hultgren, A.J., 2000, The parables of Jesus. A commentary, Wm. B. Eerdmans, Grand Rapids, MI.

Jones, P.R., 1978, 'The seed parables of Mark', Review \& Expositor 75, 519-538. http://dx.doi.org/10.1177/003463737807500404

Kirkland, J.R., 1977, 'The earliest understanding of Jesus' use of parables', Novum Testamentum 19(1), 1-21. http://dx.doi.org/10.1163/156853677X00011

Koch, D.-A., 2008, Hellenistiches Christentum, Schriftverständnis - Ekklesiologie Geschichte, Vandenhoeck \& Ruprecht, Göttingen.

Liddell, H.G., 1996, A lexicon: Abridged from Liddell and Scott's Greek-English Lexicon, Logos Research Systems, Inc, Oak Harbor, WA.

Louw, J.P., \& Nida, E.A., 1996, Greek-English lexicon of the New Testament: Based on semantic domains, United Bible Societies, New York.

MacComiskey, D.S., 2008, 'Exile and the purpose of Jesus' parables (Mark 4:10-12 Matt 13:10-17; Luke 8:9-19)', The Journal of the Evangelical Theological Society 51(1), 59-85.

Maier, G., 1995, Markus-Evangelium, Hänssler-Verlag, Heuhausen-Stuttgart.

Marcus, J., 1984, 'Mark 4:10-12 and Marcan epistemology', Journal of Biblical Literature 103(4), 557-574. http://dx.doi.org/10.2307/3260467

Marcus, J., 1986, The mystery of the Kingdom of God, Scholars Press, Atlanta, GA. (Society of Biblical Literature Dissertation Series, 90).

Marcus, J., 2000, Mark 1-8. A New Translation with Introduction and Commentary, Anchor Yale Bible, Doubleday.

Newman, R.C., 2000, 'Rabbinic Parables,' in C.A. Evans \& S.E. Porter (ed.), Dictionary of New Testament background: A compendium of contemporary biblical scholarship, pp. 909-911, InterVarsity Press, Downers Grove, IL.

Pesch, R., 1976, Das Markusevangelium I. Teil Einleitung und Kommentar zu Kap, Freiburg. (1,1-8, 26 Herders Theologischer Kommentar II/1)

Räisänen, H., 1973, Die Parabelheorie im Markusevangelium, Helsinki. (Schriften den Finnischen Exegetischen Gesellschaft 26), Pohjois-Karjalan Kirjapaino Oy Joensuu.

Scott, B.B., 1990, Hear then the parable - a commentary on the parables of Jesus, Fortress Press, Minneapolis, MN

Sellew, P., 1990, 'Oral and written sources in Mk 4:1-34', New Testament Studies 36, 234-267. http://dx.doi.org/10.1017/S0028688500015071

Sellin, G., 1983, 'Textlinguistische und semiotische Erwägungen zu Mk. 4:1-34', New Testament Studies 29(4), 508-530. http://dx.doi.org/10.1017/\$0028688500006305

Snodgrass, K.R., 1992, 'Parable,' in J.B. Green \& S. McKnight (ed.), Dictionary of Jesus and the Gospels, InterVarsity Press, Downers Grove, IL.

Suhl, A., 1965, Die Funktion der altestamentliche Zitate und Anspielungen im Markusevangelium, Gütersloher Verlagshaus, Gütersloher.

Tuckett, C.M., 1988, 'Mark's concerns in the parable chapter (Mark 4,1-34)', Biblica 69(1), 1-26.

Turner, C.H., 1993, 'Marcan usage: Notes, critical and exegetical on the second gospel', in J.K. Elliot, (ed.), The language and style of the Gospel of Mark, pp. 3-146, Brill, Leiden.

Van Bruggen, J., 1988, Marcus. Het Evangelie volgens Petrus, Uitgeversmaatschappij J.H. Kok, Kampen. (Commentaar op Het Nieuwe Testament, 3rd series (Afd. Evangeliën)

Vincent, P., 1986, 'Mark Chapter 4:10-12', Inductive Biblical Study 8(4), 179-182. 